\title{
Hydrological modelling of fine sediments in the Odzi River, Zimbabwe
}

\author{
R Lidén ${ }^{1 *}$, J Harlin' ${ }^{2}$ M Karlsson ${ }^{3}$ and M Rahmberg ${ }^{3}$ \\ ${ }^{1}$ Dept. of Water Resources Engineering, Lund Institute of Technology, Lund University, P.O. Box 118, SE-221 00 Lund, Sweden \\ ${ }^{2}$ SWECO International AB, Box 34044, SE-100 26, Stockholm, Sweden \\ ${ }^{3}$ Dept. of Earth Science, Uppsala University, Villav. 16, SE-752 36 Uppsala, Sweden
}

\begin{abstract}
Siltation of reservoirs is a major concern in Zimbabwe. Therefore, development of prediction tools is of great importance. In the present study a recently developed empirical sediment model (HBV-SED) based on a daily rainfall-runoff model was applied to simulate riverine fine sediment transport in a $2486 \mathrm{~km}^{2}$ catchment in eastern Zimbabwe. The model performance was evaluated and changes in the model structure were suggested. The modelling was, however, associated with many uncertainties due to the adopted simplification of transport processes. An analysis of the model structure and a comparison with the rating curve function was done. The required length of data for calibration purposes was evaluated and model validation through split sample and proxy basin comparison was performed. Furthermore, since the empirical model was dependent on monitored runoff and fine sediment concentrations for calibration purposes, a field measurement campaign was conducted to assess the accuracy of observed data at the station studied. The field measurements showed large errors in monitored runoff and fine sediment concentrations for the 1998/ 99 wet season, which illustrated the uncertainty in predictions of fine sediment transport based on observed data. The HBV-SED model, which was applied over a period when data were believed to be fairly accurate, simulated the fine sediment transport volume well for the validation period if it was calibrated for a minimum of four years. A shorter calibration period led to a significant increase in prediction uncertainty. The model failed to simulate individual high fine sediment peaks accurately mainly due to poor performance of the rainfall-runoff model on a daily time-scale even if the seasonal flow dynamics were described properly. In the studied catchment the HBV-SED model application resulted in equally poor $R^{2}$-values as the rating curve technique, while the estimated fine sediment volume was more accurate.
\end{abstract}

\section{Introduction}

\section{Background}

Sediment transport in natural streams is a problem all over the world and a major concern in southern Africa. Apart from loss of valuable top soils three problems can be distinguished (see $e . g$. Chenje and Johnson 1996):

- deposition of sediment material (siltation) in reservoirs which decreases the storage capacity and thus also the potential water yield

- $\quad$ reduced primary production of plankton and altered bottom vegetation due to turbidity caused by high sediment concentrations

- increased transport of pollutants, for instance pesticides, heavy metals and nutrients, which are adsorbed to the sediment particles.

In addition, flooding, due to river meandering and buried wetlands has been reported as threats caused by riverine sediment loads (Chabwela, 1991).

Siltation of reservoirs, in particular, has significant economic impacts (e.g. Lahlou, 1996). Although sediment transport is generally considered when new reservoirs are constructed, many examples of extreme reservoir sedimentation are reported in the literature. For instance, Chanson (1999) lists a number of reservoirs

* To whom all correspondence should be addressed.

III +46-40-167281; fax: +46-40-154347; e-mail: rikard.liden@sweco.se Received 19 January 2000; accepted in revised form 25 January 2001. located in five continents with extreme siltation rates (174 to 25714 $\left.\mathrm{m}^{3} \cdot \mathrm{km}^{-2} \cdot \mathrm{yr}^{-1}\right)$. Heavy riverine sediment yield is also reported in many other countries; 2000 to $25000 \mathrm{t} \cdot \mathrm{km}^{-2} \cdot \mathrm{yr}^{-1}$, in the Yellow River, China, 1050 to $3500 \mathrm{t} \cdot \mathrm{km}^{-2} \cdot \mathrm{yr}^{-1}$ in Pakistan, 100 to 1500 $\mathrm{t} \cdot \mathrm{km}^{-2} \cdot \mathrm{yr}^{-1}$ in Cyprus, 94 to $1089 \mathrm{t} \cdot \mathrm{km}^{-2} \cdot \mathrm{yr}^{-1}$ in USA (Jansson, 1982). In Southern Africa, Rooseboom (1992) estimated the average sediment yield in nine defined sediment yield regions to vary between 30 and $330 \mathrm{t} \cdot \mathrm{km}^{-2} \cdot \mathrm{yr}^{-1}$.

In Zimbabwe, the problem of erosion and siltation of reservoirs has been a major concern over a long period of time (e.g. Hudson 1957; Ward, 1980). An increasing population creates a demand for additional reservoirs for water storage and contributes to accelerated erosion due to further cultivation and an increased number of livestock. Recently several new dams have been constructed in the erosion-prone areas of the country despite the risk of rapidly decreasing capacities due to siltation. A countrywide reservoir siltation survey in the $1980 \mathrm{~s}$ displayed rates of 10 to $704 \mathrm{t} \cdot \mathrm{km}^{-2} \cdot \mathrm{yr}^{-1}$ (NORAD, 1983). Despite the gravity of the problem no attempts have so far been made to predict riverine sediment transport in Zimbabwe using deterministic models. Development and tests of prediction tools of this kind are therefore called for. In the present study a deterministic empirical model for fine suspended sediment transport was applied to the Odzi River basin $\left(2486 \mathrm{~km}^{2}\right)$ located in the eastern mountainous part of Zimbabwe.

\section{Estimation of sediment transport}

Riverine sediment transport may be divided into bedload and suspended load. Some authors further divide the suspended load into current-related load and washload. The washload particles are near to permanently in suspension because of the low falling 
velocity for small grain sizes and can be transported over long distances. The relative importance of the different types of sediment transport is highly dependent on catchment characteristics, e.g. grain size distribution and river slope, and is specific for each river basin.

Using the runoff duration curve, profile data and grain size distribution from the river bed at the E61 station in Odzi River, well-known transport formulas (Bagnold, 1966; Engelund and Hansen, 1967; Ackers and White, 1973; Van Rijn, 1984) give an average total bedload and current-related transport of 51 to 145 $\mathrm{t} \cdot \mathrm{km}^{-2} \cdot \mathrm{yr}^{-1}$. Defining fine sediment as clay and silt particles (size $<63 \mu \mathrm{m}$ ), the estimated fine sediment based on observed transport is $93 \mathrm{t} \cdot \mathrm{km}^{-2} \cdot \mathrm{yr}^{-1}$. This shows that the fine sediment contributes in the order of 40 to $65 \%$ of the total sediment transport in the river, thus indicating the importance of fine suspended sediment transport.

The fine sediment component can, however, not easily be estimated by formulas similar to the ones for current-related transport since it depends mainly on the availability of eroded material in the catchment and the transport routes to the river network. This is partly confirmed by the fact that very little clay and silt particles were found in the riverbed at the E61 station or in the upstream riverbeds (Karlsson and Rahmberg, 1999). Variables such as rainfall intensity, soil, land use, relief and human impact must therefore be considered (e.g. Stocking and Elwell, 1973a). An erosion model Soil Loss Estimator of Southern Africa (SLEMSA) has successfully been developed for Zimbabwe (Stocking and Elwell, 1973b; Elwell, 1981) and the Modified Universal Soil Loss Equation (MUSLE) (Williams, 1975) is used for sediment yield estimation in the Agricultural Catchment Research Unit (ACRU) model system, which has been applied widely in southern Africa (Schulze, 1995). However, the unknown delivery ratio from field to river restrains the use of erosion models for prediction of riverine transport. Distributed conceptual or physically-based erosion and sediment transport models; e.g. Chemicals, Runoff, and Erosion from Agricultural Management Systems (CREAMS) (USDA, 1980), (ANSWERS) (Beasly et al., 1980), The European Soil Erosion Model (EUROSEM) (Morgan et al., 1998) and the sediment model version of the Système Hydrologic Europe (SHESED) (Wicks and Bathurst, 1996), are restricted in their applications because of their large requirements of input data and computer power (Lørup and Styczen, 1996). Fine sediment is therefore often estimated by simple relationships such as the sediment- rating curve (e.g. Gregory and Walling, 1973) or by the aid of empirical models. An empirically-based approach was recently suggested by Lidén (1999), who used a catchment-scale hydrological model combined with a supply-based sediment model which was calibrated against observed data to simulate riverine sediment transport. Empirically-based models usually meet the limited data availability often experienced in developing countries, but include uncertainties because of the adopted simplifications of the natural transport processes.

Further difficulties for estimation of riverine fine sediment and sediment transport are the errors in measured transport. Van Rijn (1993) states that prediction accuracy smaller than a factor 2 for sediment transport is difficult due to measurement errors. Runoff stations located in rivers prone to sediment transport very often suffer from unstable bed conditions or siltation of weirs. The relationship between the monitored water stage and the associated runoff changes with time, resulting in major uncertainties in the observed runoff data. In Zimbabwe this problem is seen at many runoff stations. Moreover, water quality sampling is generally done occasionally with simple tools despite the temporal and spatial variation of sediment concentrations. The method applied in
Zimbabwe is to lower a milk bottle into the most reachable turbulent part of the stream, which often means close to the riverbank.

\section{Objectives}

The objectives of this study were threefold:

- Simulate the fine sediment transport (defined as clay and silt particles) for a large-scale catchment in Zimbabwe through the approach proposed by Lidén (1999);

- Develop and evaluate the methodology for Zimbabwean conditions, and

- Assess the uncertainty in the prediction of fine sediment transport due to both measurement errors and model shortfalls.

\section{Materials and methods}

\section{Study area and data base}

The catchment studied, the upper Odzi River in the eastern mountainous areas of Zimbabwe (Fig. 1), is one of the most erosion-prone areas in the country (Stocking and Elwell, 1973a). Total catchment area is $2486 \mathrm{~km}^{2}$; altitude difference is large, 950 to $2160 \mathrm{~m}$ a.s.l.; geology is dominated by granitic bedrock and insitu weathered sandy soils; population density is above 60 persons per $\mathrm{km}^{2}$ in large parts of the catchment; land use is a mixture of communal lands, commercial farms and forests; main crops are tobacco and wheat on the commercial farms and maize, rapocko and sorghum on communal lands where the number of livestock is high. The climate is seasonal with a rainy season from November to March. Average rainfall is 700 to $2000 \mathrm{~mm} \cdot \mathrm{yr}^{-1}$ and average runoff is 150 to $400 \mathrm{~mm} \cdot \mathrm{yr}^{-1}$, the upper mountainous parts receiving the highest amounts. The irregular seasonal availability of water has led to the establishment of irrigation systems. River abstractions, canals and small weirs are commonly found in the catchment. The three main reservoirs on the Odzi River are Osborne, Smallbridge and the Odzani. The Odzani and Smallbridge provide the city of Mutare with freshwater, while the Osborne Dam (not shown in Fig. 1) was constructed in 1990 for downstream irrigation purposes. The dam, which is located just downstream of the Nyatanda and Odzi confluence, has a total capacity of $400 \mathrm{Mm}^{3}$ and acts as a

\begin{tabular}{|l|c|c|}
\hline \multicolumn{3}{|c|}{ TABLE 1 } \\
Statistical description of the observed daily \\
runoff and fine sediment concentration data \\
from Station E61 in Odzi River
\end{tabular}




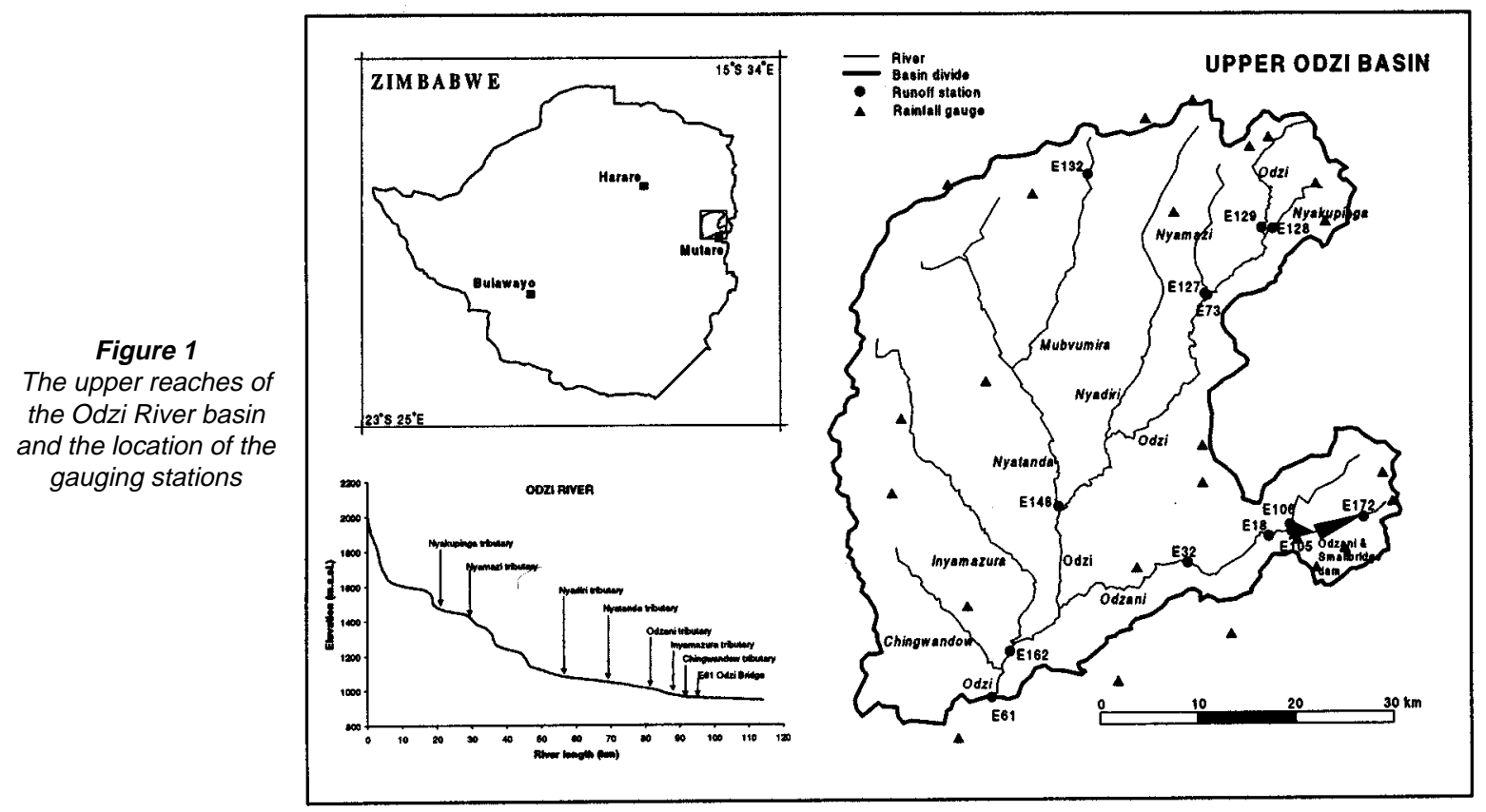

sediment trap for a large part of the catchment. Because of Osborne's effect on the runoff and sediment transport at the outlet of the catchment, the period studied was chosen prior to the construction start of the dam.

The runoff station studied in detail, E61, was established in 1960 when a gauging tower equipped with an automatic recorder was constructed at the station. The river width is approximately $100 \mathrm{~m}$ and the river slope is $0.14 \%$. The runoff station has a natural control close to the gauging tower and the original rating curve was established through current meter measurements during 1961 to 72. An updating of the rating curve was done in 1978 after flow gauging with tritium (Wurzel and Ward, 1982). Daily runoff data are available at E61 since 1962 with only short gaps in the record. Sediment sampling through lowering a bottle at the riverbank (grab sampling) was performed during the rainy seasons between 1978 and 1987 at the gauging tower. During low flows, one sample per day was taken, while during high flows or changing flows, several samples per day were collected. The concentration of fine sediment was determined from spectrophotometric absorbance, which was calibrated against detailed volume-mass analyses of material passing a $63 \mu \mathrm{m}$ filter. Table 1 shows the characteristics of observed runoff and fine sediment at station E61 used in this study. Available meteorological data for modelling purposes were daily rainfall data from 23 rainfall gauges (Fig.1) and monthly evaporation from three A-pans located within or adjacent to the catchment studied. Additionally to data from E61, daily runoff data were available from a further 12 runoff stations within the study area (Fig. 1).

\section{Fine sediment modelling}

The HBV-SED model (Lidén, 1999) is based on the latest variant of the Hydrologiska Byråns Vattenbalansmodell(HBV-96) rainfallrunoff model (Lindström et al., 1997), which can be classified as a semi-distributed conceptual hydrological model. It uses sub-basins as primary hydrological units in which an area-elevation distribution and a crude classification of land use (dense vegetation, open areas, and lakes) are made. The hydrological model has a number of free parameters, values of which are found by calibration against river runoff. It is usually run with daily time steps and input data are daily precipitation and average monthly potential evaporation. Areal averages of the climatological data are computed separately for each sub-basin by a simple weighing procedure and the rainfall data is further corrected for elevation by constant lapse rates. Reservoirs are described in the model set-up through storage curves, spillway rating curves and regulation schemes and further artificial influence, e.g. bifurcation and abstractions, is included through simple model routines. A more detailed description of the HBV-96 hydrological model structure and applications is found in Bergström, 1995; Lindström et al., 1997.

The HBV-SED model uses daily areal precipitation and river runoff for each sub-basin as input data from the hydrological model. It consists basically of two parts: an accumulation and a release routine. The accumulation of available sediment in each sub-basin is a function of the areal precipitation in the sub-basin. A linear relationship between the log values of sediment production and rainfall is used and the accumulation routine is run continuously, adding mobilised sediment to the sediment storage that is available to be flushed out. The release routine discharges fine sediment at the outlet of each sub-basin depending on river runoff and the amount of stored sediment. The model equations, based on the principle of continuity, are:

$$
\begin{aligned}
& \frac{d H_{\text {sed }}}{d t}=\mathrm{a}[P(t)]^{\mathrm{b}}-H_{\text {sed }}(t) \cdot R \\
& R=\left(\frac{Q(t)}{\mathrm{c}}\right)^{\mathrm{d}} \quad \text { if } \quad Q<c \\
& R=1 \quad \text { if } \quad Q \geq \mathrm{c}
\end{aligned}
$$

where:

$\boldsymbol{H}_{\text {sed }}\left(\mathrm{t} \cdot \mathrm{km}^{-2}\right)$ is the sediment storage,

$\boldsymbol{P}\left(\mathrm{mm} \cdot \mathrm{d}^{-1}\right)$ is rainfall, $\boldsymbol{Q}\left(\mathrm{mm} \cdot \mathrm{d}^{-1}\right)$ is runoff,

$\boldsymbol{R}\left(\mathrm{d}^{-1}\right)$ is the release rate,

$\boldsymbol{t}(\mathrm{d})$ is a time variable and

$\mathbf{a}\left(\mathrm{t} \mathrm{mm}^{-\mathrm{b}} \cdot \mathrm{km}^{-2} \cdot \mathrm{d}^{\mathrm{b}-1}\right), \mathbf{b}$ (dimensionless), $\mathbf{c}\left(\mathrm{mm} \mathrm{d}^{1 / \mathrm{d}-1}\right)$ and $\mathbf{d}$

(dimensionless) are empirical model parameters.

Eq. (1) can be solved for each sub-basin in a catchment and the fine 

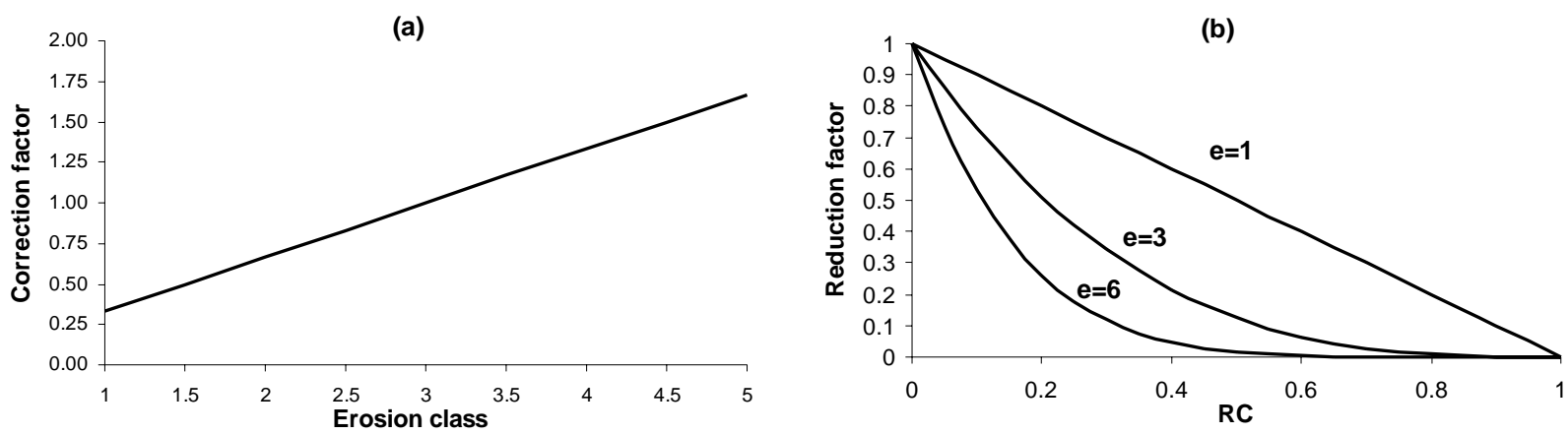

Figure 2

New correction factors for erosivity (a) and vegetation cover (b) introduced in the HBV-SED accumulation routine for Zimbabwean applications. Erosion index (EI) is based on Stocking and Elwell (1973a), RC is the HBV-96 estimate of the area with no soil moisture deficit in a catchment and e is an HBV-SED parameter.

sediment for all sub-basins are summed each day to get the total yield for the whole catchment, assuming no further deposition in the main river channels. The model parameters are determined through calibration against observed riverine fine sediment concentrations. For further details about the HBV-SED the reader is referred to Lidén (1999).

In the original model development the model erosion parameters $\mathbf{a}$ and $\mathbf{b}$ were used to describe the erosion characteristics in the whole catchment, thus lumping the effects of soil erodibility, slope, land use and vegetation. The results obtained by Lidén (1999), who applied the model to a small $\left(200 \mathrm{~km}^{2}\right)$ tropical mountainous catchment in South America, were satisfactory despite this crude model approach. However, for the semi-arid conditions in Zimbabwe and the large scale, this simplification was judged to be too crude and the following developments were suggested:

- A correction factor (Fig. 2a) for erosivity due to slope, soil type and land use was applied to the accumulation of sediment in each sub-basin. The correction factor was based on erosion classes (1 to 5) as described by Stocking and Elwell (1973a) where 1 and 5 denote low and high erosion hazard, respectively. The erosion class for average slope, soil and land use was merged together by the mean value to get an erosion index (EI) for each sub-basin.

- A reduction factor (Fig. 2b) for vegetation cover during the wet season was applied to the accumulation of sediment in each sub-basin based on the HBV-96 simulated soil moisture deficit and assuming a relation between soil moisture and vegetation cover. The reduction factor is controlled by a free model parameter, since the relation between soil moisture deficit, vegetation and soil-binding effect is assumed to vary with the catchment characteristics.

For the applications in the present study, the coefficient a in Eq. (1) thus becomes:

$$
\mathrm{a}=\mathrm{a}^{\prime}\left[\frac{\mathrm{EI}}{3}\right][1-R C(t)]^{\mathrm{e}}
$$

where:

$\boldsymbol{R C}$ (dimensionless) is the HBV-96 estimate of the area with no soil moisture deficit in a catchment,

EI (dimensionless) is an erosion index based on slope, soil and land use,

$\mathbf{a}^{\prime}\left(\mathrm{t} \mathrm{mm} \mathrm{m}^{-\mathrm{b}} \cdot \mathrm{km}^{-2} \cdot \mathrm{d}^{\mathrm{b}-1}\right)$ and $\mathbf{e}$ (dimensionless) are empirical parameters and

$\boldsymbol{t}(\mathrm{d})$ is a time variable.
A further development of the HBV-SED model was an automatic calibration routine for the sediment parameters based on the Brent optimisation routine (Brent, 1973) and a calibration procedure similar to the one used for the HBV-96 hydrological model (Harlin, 1991; Lindström, 1997). A criterion combining both the explained variance for sediment concentration $\boldsymbol{R}^{2}{ }_{\text {conc }}$ and total volume error $\boldsymbol{V} \boldsymbol{E}$ for sediment transport was used to find the optimum parameter set:

$$
R^{2} W=R_{\text {couc }}^{2}-A B S(V E)
$$

where:

$$
\begin{aligned}
& R_{\text {conc }}^{2}=1-\frac{\sum\left(C_{\text {sim }}-C_{\text {obs }}\right)^{2}}{\sum\left(C_{\mathrm{obs}}-\overline{C_{\mathrm{obs}}}\right)^{2}} \\
& V E=\frac{\sum\left(Q_{\text {sim }} C_{\text {sim }}\right)-\left(Q_{\text {obs }} C_{\text {obs }}\right)}{\sum\left(Q_{o b s} C_{o b s}\right)}
\end{aligned}
$$

The HBV-96 hydrological model was set up for the upper Odzi catchment down to the E61 station using observed daily rainfall and monthly A-pan evaporation as input data. Rainfall data were corrected with $5 \%$ per $100 \mathrm{~m}$ increase in altitude, based on an analysis of adjacent rainfall gauges. An A-pan coefficient of 0.8 was applied to evaporation data. Two-land use categories were used, namely open fields and forested areas. River abstractions were included according to historical records of water rights. The Odzani and Smallbridge Reservoirs were described regarding capacity and regulation procedures. Calibration of the hydrological model parameters was done against daily runoff data from the 13 runoff stations for the period October 1978 to September 1983. The HBV-SED model was set up for the upper Odzi catchment using a sub-basin division with 12 sub-basins of similar size (Fig. 3) for which erosion classes were calculated (Table 2). For each subbasin, hydrological parameters were set according to the calibration done for the closest river with a runoff station and station weights were defined based on geographical locations of the rainfall gauges. Since the Odzani and Smallbridge Reservoirs are deep and fairly large, they were assumed to have $100 \%$ trap efficiency, thus making no contribution to the fine sediments downstream. The original HBV-SED model as well as the version including the new correction factors (Fig. 2) were then calibrated against observed daily fine sediment at the E61 station using the new automatic calibration routine. The sediment parameters were assumed to be lumped for the whole Odzi catchment and the model was run for a six-year warm-up period to avoid effects from starting conditions.

The fine sediments at E61 simulated by the HBV-SED was compared with the fine sediments computed by two conventional 


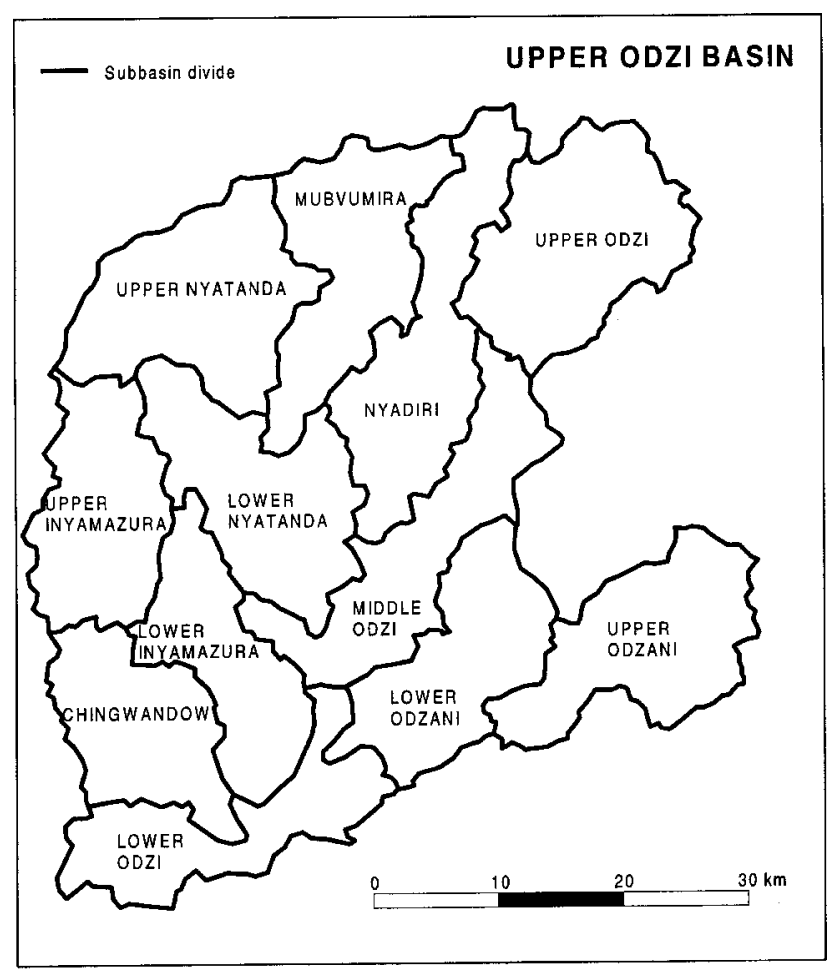

Figure 3

Sub-basin division for the HBV-SED model application on the upper Odzi River catchment

methods: the sediment-rating curve for daily mean concentration, and the sediment rating curve for mean loads within runoff classes. The equations for the sediment rating curves are:

$$
\begin{gathered}
W L_{\text {conc }}=\alpha Q^{\beta} \\
W L_{t r s p r t}=\alpha^{\prime} Q^{\beta^{\prime}}
\end{gathered}
$$

where:

$W L_{\text {conc }}\left(\mathrm{g} \cdot \ell^{-1}\right)$ is fine sediment concentration

$W L_{\text {trsprt }}^{\text {conc }}\left(\mathrm{t} \cdot \mathrm{d}^{-1}\right)$ is fine sediment transport

$Q\left(\mathrm{~mm} \cdot \mathrm{d}^{-1}\right)$ is river runoff

$\alpha, \beta, \alpha^{\prime}$ and $\beta^{\prime}$ are empirical coefficients.

The coefficients $\alpha$ and $\beta$ in Eq. (8) were optimised for the calibration period by the method of least squares for log-transformed fine sediment concentration and runoff and a correction for transformation bias (Duan, 1983) was applied. For Eq. (9) the runoff was divided into ten runoff classes for which the average runoff and fine sediment were calculated. $\alpha^{\prime}$ and $\beta^{\prime}$ were then optimised for the calibration period in the same way as $\alpha$ and $\beta$ but using the average runoff and fine sediment for the runoff classes. The latter method has the advantage of reducing the influence of the frequent low fine sediment values in records with a skewed distribution (Jansson, 1996).

The main differences between the HBV-SED model structure and the rating curve techniques are:

- The driving variable for the generation of fine sediment in HBV-SED is rainfall instead of river runoff.

- HBV-SED simulated riverine fine sediment concentration depends on the amount of fine sediment storage, i.e. the model is supply-based, giving possibilities to describe the hysteris effect often found for sediment transport.

- HBV-SED is driven by local variables for each sub-basin, i.e. generation and release of fine sediment is different in different parts of the catchment depending on the spatial rainfall and runoff distribution.

Simulated runoff and fine sediment were validated during the independent validation period October 1983 to September 1987. HBV-96 simulated runoff was used to calculate fine sediment transport during the validation period for the sediment rating curve methods.

\section{Analysis of uncertainties}

There are several uncertainties present in the prediction of fine sediment transport using a model approach such as the HBV-SED. However, in this study three uncertainties were emphasised and evaluated:

- Systematic errors in observed runoff, which yield wrong parameters for the empirically-based hydrological model.

- Systematic errors in the observed fine sediment, which yield wrong parameters for the empirically-based sediment model.

- Short data records, which cause model prediction uncertainty for the independent validation period.

It was further assumed that, for the river studied, the main error in observed runoff was due to an incorrect relation between the monitored water stage and the actual runoff and the main error in observed fine sediment was due to a non-representative sampling position by taking only grab samples at the riverbank.

To evaluate the accuracy of observed runoff and fine sediment data, a field measurement campaign was performed at the E61 runoff station. Detailed river flow gaugings were made on 18 occasions in total from a cableway system located 10 m upstream of the gauging tower during the rainy season 1998/99. Standard type current meters were used and WMO gauging standards were followed (WMO, 1980). Normally the three-point method was applied because of abnormal velocity profiles in the river section and measurements were made at a minimum of 25 measurement verticals across the river section. Depth-integrated sediment sampling with an US-D74 sampler was done during a period of three weeks in January/February 1999. Nine detailed sectional samplings were performed with an average sectioning of $2 \mathrm{~m}$. In parallel to the sectional sampling, grab samples were taken for comparison. Further sampling with a fixed time interval was done to assess the temporal variation of the fine sediment concentration. In total, 219 depth-integrated samples were taken. Subsequent laboratory analyses of the samples were conducted and fine sediment concentrations, defined as the concentration of material passing through a $63 \mu \mathrm{m}$ filter, were determined through volume-mass estimations of the samples.

To analyse the uncertainties in the HBV-96 and HBV-SED model parameters due to short calibration records, a split sample test was conducted whereby the models were calibrated for different periods during October 1978 to September 1983 and the results of the validation period October 1983 to September 1987 were compared. For the five-year period 15 calibrations were done, 5 one-year, 4 two-year, 3 three-year, 2 four-year and 1 five-year. For the hydrological model, a simplified model set-up, assuming lumped hydrological parameters for the whole Odzi catchment, was used, i.e. only runoff data at E61 were used for calibration. This 
TABLE 2

Catchment characteristics and erosion classification for the Odzi River sub-basins. Data are collected from 1:50,000 topographical maps, 1:1,000,000 soil map and 1:500,000 land unit maps (Anderson et al., 1993). Soil type is given according to the classification of Zimbabwe and erosion index is defined according to Stocking and Elwell (1973a) on a scale from 1 (low) to 5 (high).

\begin{tabular}{|c|c|c|c|c|c|c|c|c|c|}
\hline Sub-basin & $\begin{array}{l}\text { Area } \\
\left(\mathrm{km}^{2}\right)\end{array}$ & $\begin{array}{l}\text { Altitude } \\
\text { (m a.s.I.) }\end{array}$ & $\begin{array}{c}\text { Average } \\
\text { slope } \\
\text { (degrees) }\end{array}$ & $\begin{array}{l}\text { Erosion } \\
\text { class }\end{array}$ & Main soil type & $\begin{array}{l}\text { Erosion } \\
\text { class }\end{array}$ & $\begin{array}{l}\text { Land } \\
\text { classification }\end{array}$ & $\begin{array}{l}\text { Erosion } \\
\text { class }\end{array}$ & Erosion index (EI) \\
\hline Upper Odzi & 248 & $1400-2160$ & 7.1 & 4 & $\begin{array}{l}\text { 7G: sandy loam, } \\
\text { orthoferrallitic }\end{array}$ & 1 & Forest land & 1 & 2.0: Below average \\
\hline Nyadiri & 236 & $1080-2160$ & 7.4 & 4 & $\begin{array}{l}\text { 6G,7G: sand, sandy } \\
\text { loam, paraferrallitic }\end{array}$ & 2 & $\begin{array}{l}\text { Communal lands } \\
>60 \text { p.p.km² }\end{array}$ & 5 & 3.7: Above average \\
\hline Mubvumira & 216 & $1120-1880$ & 6.1 & 4 & $\begin{array}{l}\text { 6G,7G: sand, sandy } \\
\text { loam, paraferrallitic }\end{array}$ & 2 & $\begin{array}{l}\text { Communal lands } \\
>60 \text { p.p.km² }\end{array}$ & 5 & 3.7: Above average \\
\hline Upper Nyatanda & 242 & $1150-1900$ & 5.4 & 3 & $\begin{array}{l}\text { 6G,7G: sand, sandy } \\
\text { loam, paraferrallitic }\end{array}$ & 2 & $\begin{array}{l}\text { Communal lands } \\
40-60 \text { p.p.km² }\end{array}$ & 5 & 3.3: Average \\
\hline Lower Nyatanda & 224 & $1050-1900$ & 5.7 & 3 & $\begin{array}{l}\text { 5G: coarse sand } \\
\text { fersiallitic }\end{array}$ & 3 & $\begin{array}{l}\text { Communal lands } \\
40-60 \text { p.p...km² }\end{array}$ & 5 & 3.7: Above average \\
\hline Middle Odzi & 212 & $1040-1870$ & 5.2 & 3 & $\begin{array}{l}\text { 5G,5E: clay, sand } \\
\text { fersiallitic }\end{array}$ & 3 & $\begin{array}{l}\text { Communal lands } \\
40-60 \text { p.p.km² }\end{array}$ & 5 & 3.7: Above average \\
\hline Upper Inyamazura & 187 & $1100-1600$ & 4.2 & 3 & $\begin{array}{l}\text { 5G: coarse sand } \\
\text { fersiallitic }\end{array}$ & 3 & $\begin{array}{l}\text { Communal lands } \\
40-60 \text { p.p.km² }\end{array}$ & 5 & 3.7: Above average \\
\hline Lower Inyamazura & 170 & $980-1600$ & 2.4 & 2 & $\begin{array}{l}\text { 5G: coarse sand } \\
\text { fersiallitic }\end{array}$ & 3 & Commercial farms & 2 & 2.3: Below average \\
\hline Upper Odzani & 215 & $1160-2030$ & 4.5 & 3 & $\begin{array}{l}\text { 7G: sandy loam, } \\
\text { orthoferrallitic }\end{array}$ & 1 & Forest land & 1 & 1.7: Below average \\
\hline Lower Odzani & 190 & $1020-1890$ & 5.0 & 3 & $\begin{array}{l}\text { 5G: coarse sand } \\
\text { fersiallitic }\end{array}$ & 3 & $\begin{array}{l}\text { Communal lands } \\
20-40 \text { p.p. } \mathrm{km}^{2}\end{array}$ & 4 & 3.3: Average \\
\hline Chingwandow & 168 & $960-1450$ & 1.7 & 1 & $\begin{array}{l}\text { 5G:coarse sand } \\
\text { fersiallitic }\end{array}$ & 3 & Commercial farms & 2 & 2.0: Below average \\
\hline Lower Odzi & 178 & 950-1 570 & 2.5 & 2 & $\begin{array}{l}\text { 5G,5E: clay, sand } \\
\text { fersiallitic }\end{array}$ & 3 & Commercial farms & 2 & 2.3: Below average \\
\hline
\end{tabular}


Figure 4

Recorded errors in monitored runoff and fine sediment concentrations during the 1998/

99 rainfall season. Errors in runoff are calculated as the difference between the value based on water stage observations and the value obtained from detailed current meter gaugings. Errors in concentrations are defined as the difference between the grab sample concentration and the average concentration of detailed sectional depthintegrated sediment sampling.
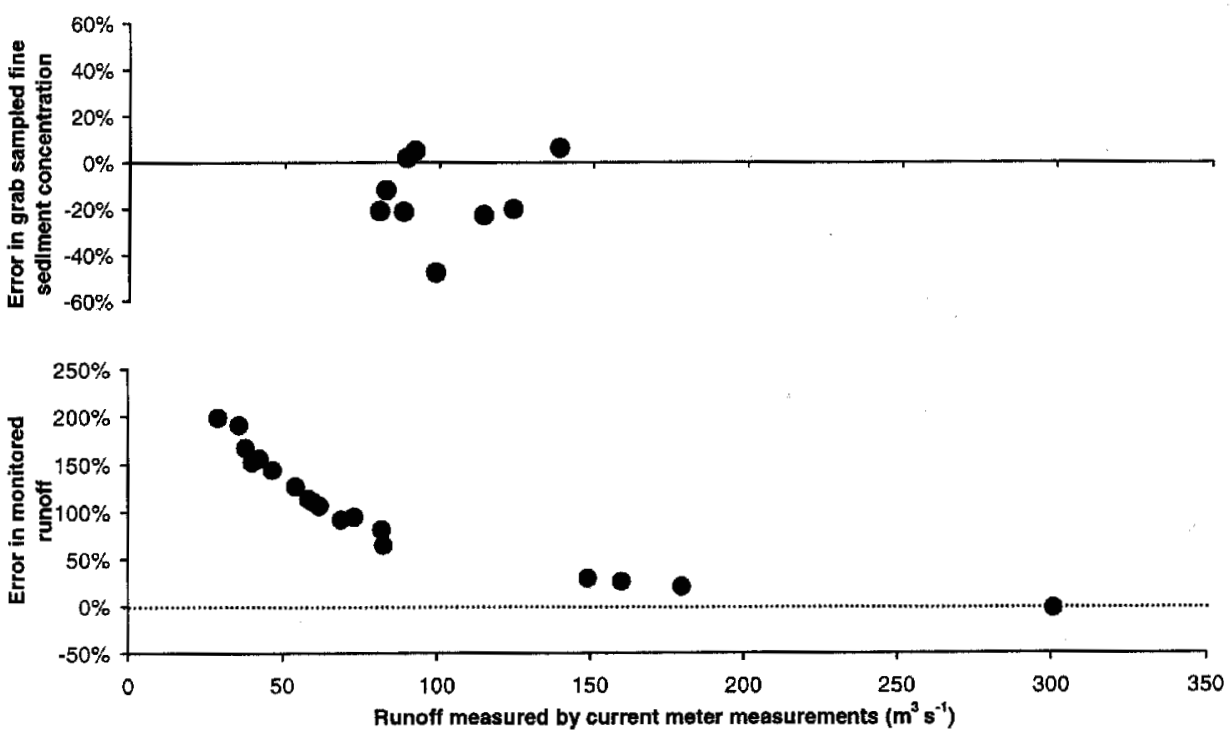

hydrological and sediment modelling set-up was further validated though a proxy basin test based on comparison with independent data from the Nyatanda tributary. In all applications, automatic calibration routines were used for both the hydrological and sediment models.

\section{Results and discussion}

\section{Field measurements}

The current meter gaugings and depth-integrated sediment sampling show both significant errors in monitored data (Fig. 4). The relative error in observed runoff was inversely proportional to the magnitude of runoff, probably as a result of changes in the river bed from deposition of sediment material after the rating curve had been established. The results illustrate the problems of using natural control stations in rivers with large sediment transport. Considering that the median value for runoff at E61 based on monitored data from 1962 to 87 is $5 \mathrm{~m}^{3} \mathrm{~s}^{-1}$ (Table 1), it is likely that the total runoff volume, and thus also the monitored fine sediment, during the $1998 / 99$ season is overestimated by a factor of at least 2. Care should be taken when predicting runoff and sediment transport on monitored data from a station, such as E61, if the relation between water stage and runoff is not regularly updated.

The number of detailed sediment gaugings in the section was too small to draw any extensive conclusions regarding the probability distribution of the error in fine sediment concentration when the grab sampling method is applied. The results (Fig. 4), however, indicate that the error is independent of the amount of runoff and that it is biased towards an underestimation $(+10 \%$ to $-50 \%)$ of the concentration compared to the sectional average. The temporal samples taken with the depth-integrated sampler with a 5 or $10 \mathrm{~min}$ interval showed that the concentration of fine sediment was fairly stable over time $(4 \%>\mathrm{CV}>32 \%)$. This indicates that the practice of taking one sample during low flows and a few samples per day during high or changing flows is sufficient to get a fair estimate of the average daily concentration of fine sediment at the river studied. It indicates further that a time step of one day for runoff and sediment modelling is adequate to describe fine sediment transport. It should, however, be pointed out that no extensive rainfall was falling in the adjacent area of the station at the time of the temporal sampling.

\section{HBV-SED model evaluation}

Empirically-based models are especially sensitive to systematic errors in observed data since they are transferred through the model by the calibration procedure. Based on the results from the field measurements at E61, an in-depth evaluation of the model performance is associated with difficulties due to the uncertainties in observed data even when modelling was performed with data for the period just after the updating of the rating curve. The evaluation is focused on a qualitative comparison between the HBV-SED models and the rating curve techniques, rather than a quantitative evaluation of the model performance. The optimum parameters for the original HBV-SED version gave $\mathbf{a}=0.08, \mathbf{b}=1.13, \mathbf{c}=38.3$, $\mathbf{d}=1.67$. When the correction factors described in Eq. (4) were applied, $\mathbf{a}^{\prime}=0.12$ and $\mathbf{e}=1.19$. The rating curve techniques gave $\boldsymbol{\alpha}=0.30, \boldsymbol{\beta}=0.96, \boldsymbol{\alpha}^{\prime}=903$ and $\boldsymbol{\beta}^{\prime}=1.65$. The results obtained for the calibration and validation periods are shown in Table 3 and a graphical presentation of the HBV-SED variables is shown in Fig. 5. The modelling showed poor $\boldsymbol{R}^{2}$-values for fine sediment transport during the independent validation period for all methods applied, which was mainly because neither the HBV-SED nor the rating curves could simulate single high peaks in fine sediment transport (Fig. 5). The HBV-SED models, however, indicated a better volume estimation of transported fine sediment compared to the rating curve techniques (Table 3 ).

The supply-based HBV-SED approach generally gives higher exponent $\mathbf{d}$ values for the release function compared to the rating curve exponent $\boldsymbol{\beta}^{\prime}$ since low concentration values during high runoff at the end of a storm event or at the end of the flow season can be explained by a depleted sediment storage instead of being compensated by a low runoff exponent. The observed optimum values of $\mathbf{d}$ and $\boldsymbol{\beta}^{\prime}$, however, are similar, which indicates that the fine sediment transport in the Odzi River is not dependent mainly on deposition within or close to the river channels. During these conditions, the HBV-SED never empties the sediment storage and the release routine reduces to a sediment rating curve with the intercept $\boldsymbol{\alpha}^{\prime}=\boldsymbol{H}_{\text {sed }}[\mathbf{c}]^{-\mathbf{d}}$, and exponent $\boldsymbol{\beta}^{\prime}=\mathbf{d}$. The storage variable $\boldsymbol{H}_{\text {sed }}$, however, varies with time and the intercept value also varies. $\boldsymbol{H}_{\text {sed }}$ ' can be said to depend on the hydrological memory, which can be seen in Fig. 6. The storage is high after dry periods while it falls rapidly when a very wet season occurs. The HBV-SED model takes into account the conditions prior to the calibration period, which could be a possible explanation to the better performance for fine 


\begin{tabular}{|c|c|c|c|c|c|c|}
\hline \multicolumn{7}{|c|}{$\begin{array}{l}\text { TABLE } 3 \\
\text { Explained variance }\left(R^{2}\right) \text { for daily fine sediment concentration and transport and } \\
\text { volume error }(V E) \text { for the calibration and independent validation periods using } \\
\text { different methods to simulate sediment transport at the E61 site. }\end{array}$} \\
\hline \multirow[t]{2}{*}{ Model } & \multicolumn{3}{|c|}{ Calibration 1978-83 } & \multicolumn{3}{|c|}{ Validation 1983-87 } \\
\hline & $\mathbf{R}_{\text {conc }}^{2}$ & $\mathbf{R}^{2}{ }_{\text {trsprt }}$ & $\mathrm{VE}_{\text {trsprt }}$ & $\mathbf{R}_{\text {conc }}^{2}$ & $\mathbf{R}^{2}{ }_{\text {trsprt }}$ & $V E_{\text {trsprt }}$ \\
\hline Original HBV-SED model & 0.49 & 0.60 & $\pm 0 \%$ & 0.30 & 0.38 & $+4 \%$ \\
\hline $\begin{array}{l}\text { HBV-SED model incl. corr. } \\
\text { factors }\end{array}$ & 0.46 & 0.56 & $\pm 0 \%$ & 0.32 & 0.39 & $+6 \%$ \\
\hline $\begin{array}{l}\text { HBV-96 + Sediment rating } \\
\text { curve, daily concentrations }\end{array}$ & 0.35 & $0.59^{\#}$ & $+9 \%$ & 0.23 & 0.40 & $-20 \%$ \\
\hline $\begin{array}{l}\text { HBV-96 + Sediment rating } \\
\text { curve, mean loads }\end{array}$ & - & $0.84^{\#}$ & $-7 \%$ & - & 0.42 & $-25 \%$ \\
\hline
\end{tabular}

sediment transport volume by HBV-SED compared to the rating curve techniques. Using the obtained values of the parameters c and d, Fig. 6 shows that the HBV-SED simulated intercept values vary between approximately 600 and 1750 , which should be compared to the result of the rating curve technique $\left(\boldsymbol{\alpha}^{\prime}=903\right)$.

Since the HBV-SED model uses a calibration method based on the $\boldsymbol{R}^{2} \boldsymbol{W}$ criterion, which emphasises transport volume, the optimal parameter set leads to good model performance during medium to high flows, but overestimated concentrations during low flows (Fig. 5). If siltation of dams is the main purpose of

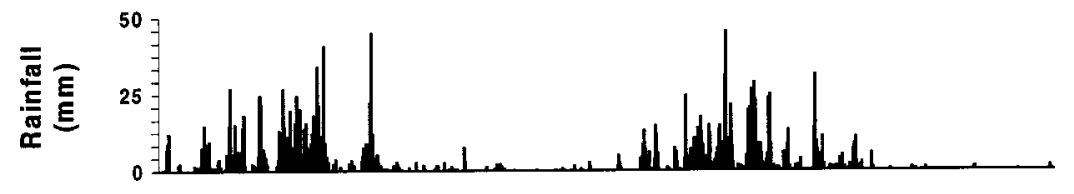
modelling sediment transport this error is, however, of minor significance since the transport is very low during the low-flow season. The semi-distribution into sub-basins used in the HBV-SED model enables the inclusion of different erosion characteristics for different parts of the catchment using the HBV-SED model. Furthermore, utilising a hydrological model as a base for sediment modelling gives the opportunity to use hydrological variables other than rainfall and runoff. However, for the modelling of fine sediment transport at the E61 site, where data were available for calibration, the inclusion of correction factors for spatial variation in erosivity and seasonal vegetation cover did not yield any improvements (Table 3 ). This suggests that when data are available for calibration, one or two parameters are sufficient to conceptually describe the accumulation of sediment in a catchment.

The HBV-96 hydrological model gave low volume errors and explained variances (Nash and Sutcliffe, 1970) between 53 to $87 \%$ for the independent validation period at the 13 runoff stations in the catchment, the lower values for the smaller sub-basins. This indicates that a daily conceptual rainfall-runoff model can reasonably well describe the seasonal dynamic of river runoff in the region with daily rainfall data as driving variables, which has also been shown by e.g. Tarboton and Schulze, 1991; Hughes, 1997; Lørup et al., 1998; Smakhtin et al., 1998. However, for estimation of material transport, the importance of correct runoff on a daily time step is crucial since riverine transport is related to runoff to the power of more than one and the bulk of material can be transported during a few single storm events. Figure 7 illustrates that the single fine sediment peaks are simulated incorrectly due to the error in the runoff modelling, even if the seasonal dynamic of runoff is modelled reasonably well. The 

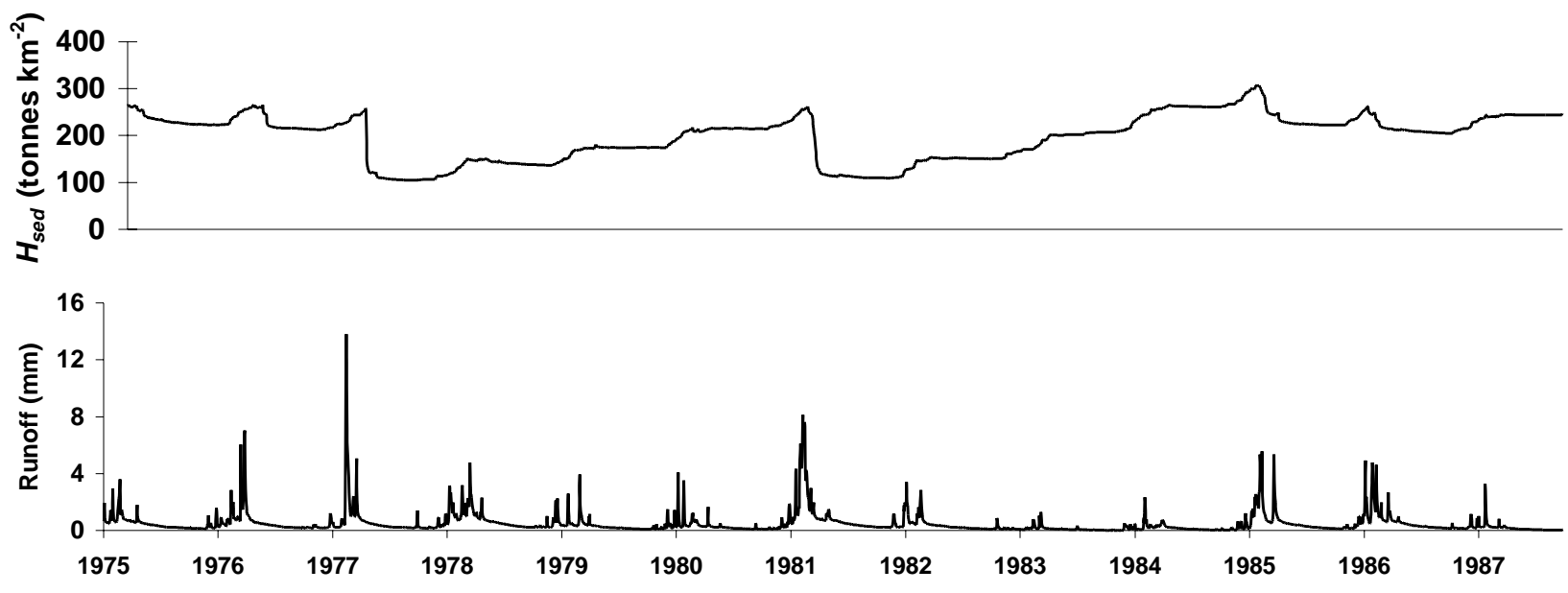

Figure 6

Simulated runoff $Q$ and sediment storage $H_{\text {sed }}$ by the HBV-SED for the period 1975-1987
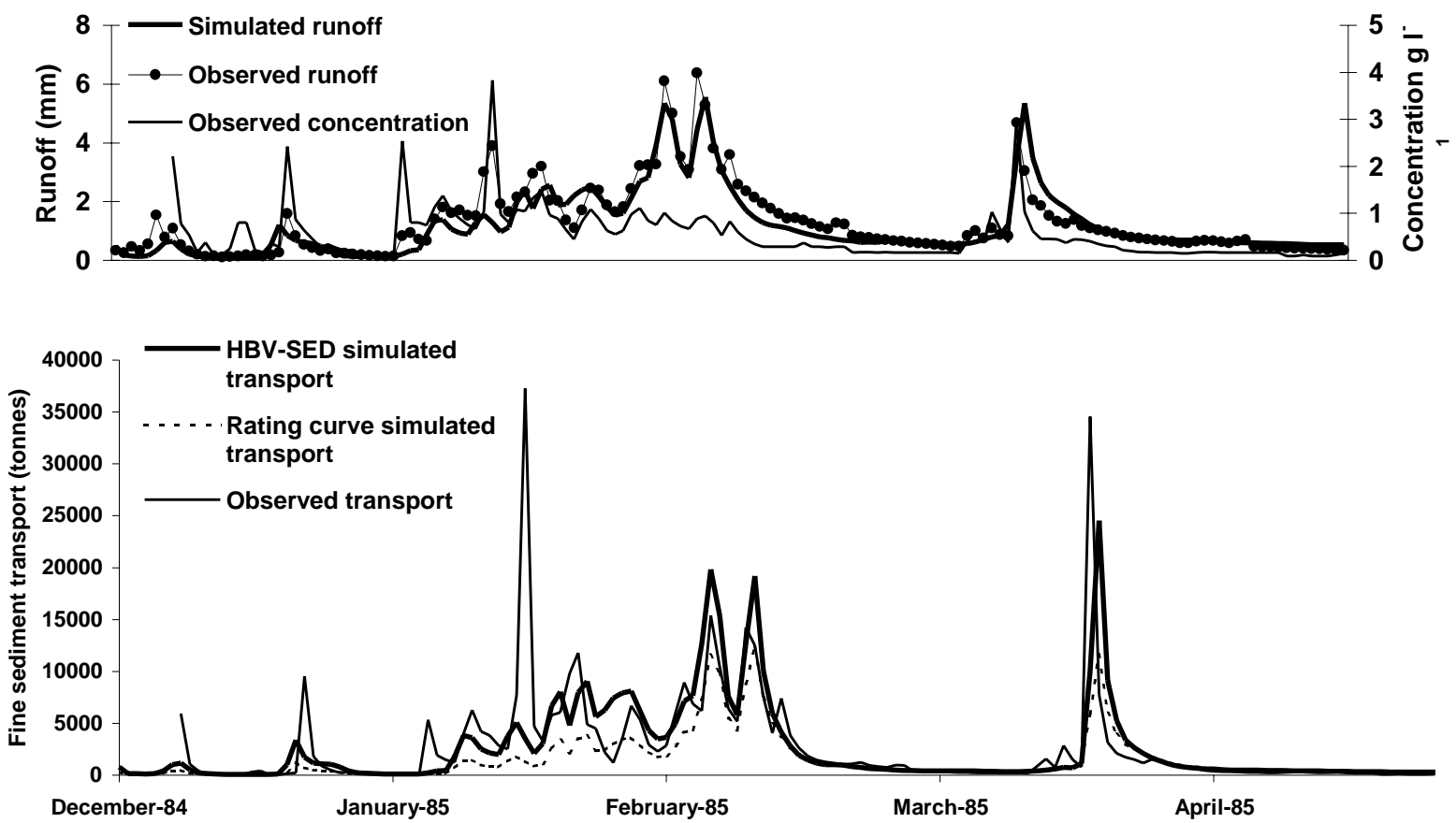

Figure 7

Detailed results of the HBV-SED model for Zimbabwe and the rating curve technique using mean load within runoff classes for the 1984/85 season. Simulated runoff is used to calculate fine sediment transport for both methods

double effect of an error in modelled runoff data is, for instance, seen during the transport peak in mid-January 1986 when the HBVSED model underestimates both the runoff and thus also the fine sediment concentration, causing a major underestimation of the daily transport. The importance of a well-performing hydrological model should therefore be emphasised to obtain a good material transport prediction. HBV-96 model applications throughout Zimbabwe (Mawere et al., 1999) and applications of similar models in the region (Hughes, 1997) have shown that the hydrological model performance decreases for drier areas, indicating that material transport modelling in such areas becomes even more uncertain than in the studied catchment.

The uncertainty in model performance both for the hydrological and sediment models because of inadequate calibration data records was illustrated with split sample validation tests, Fig. 8. The results for the 5-year calibration differ slightly from the result presented in Table 3 since a simplified HBV-96 set-up with lumped hydrological parameters was used. A minimum of four years with concentration data was needed for the HBV-SED model to produce good results for the validation period. Shorter records gave considerable volume errors and the result was dependent on the years that had been used. The HBV-SED model seemed to be more sensitive to short records in the concentration data rather than short runoff records, since the rainfall-runoff model showed relatively low volume errors, even when only one year of observed runoff was used for calibration. To further analyse the model, a proxy basin validation approach (Klemes, 1986) was adopted using 2 years of independent data from the Nyatanda tributary, Fig. 9. This test confirmed the 

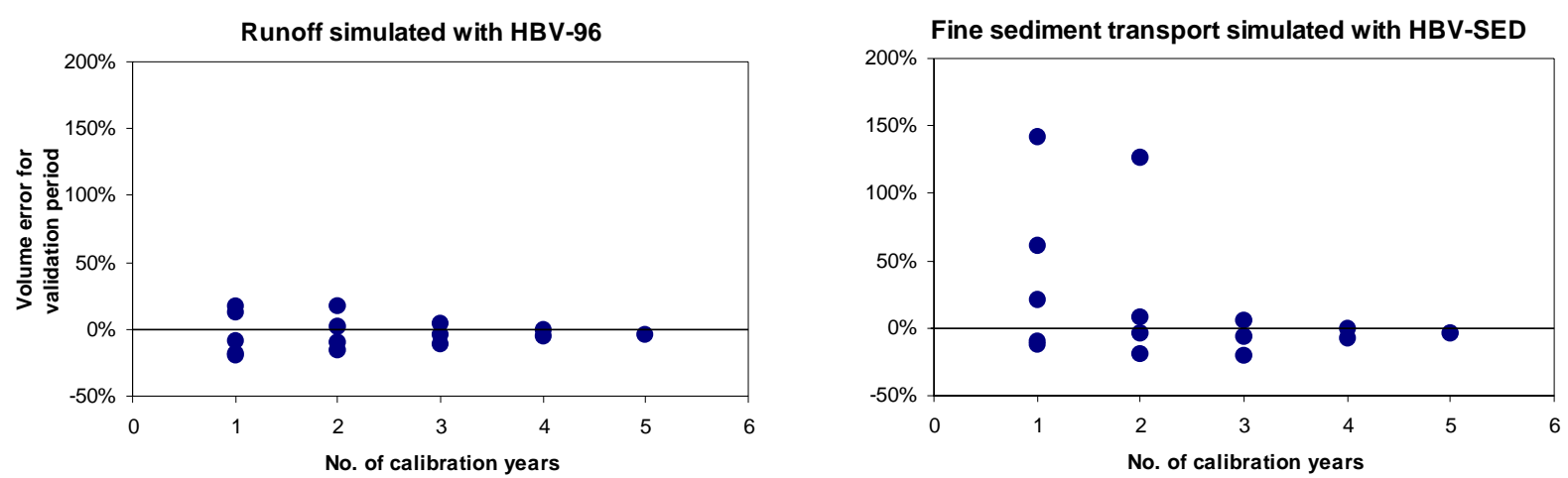

Figure 8

Volume errors for the validation period if different number of years are used for calibration of the HBV-SED model

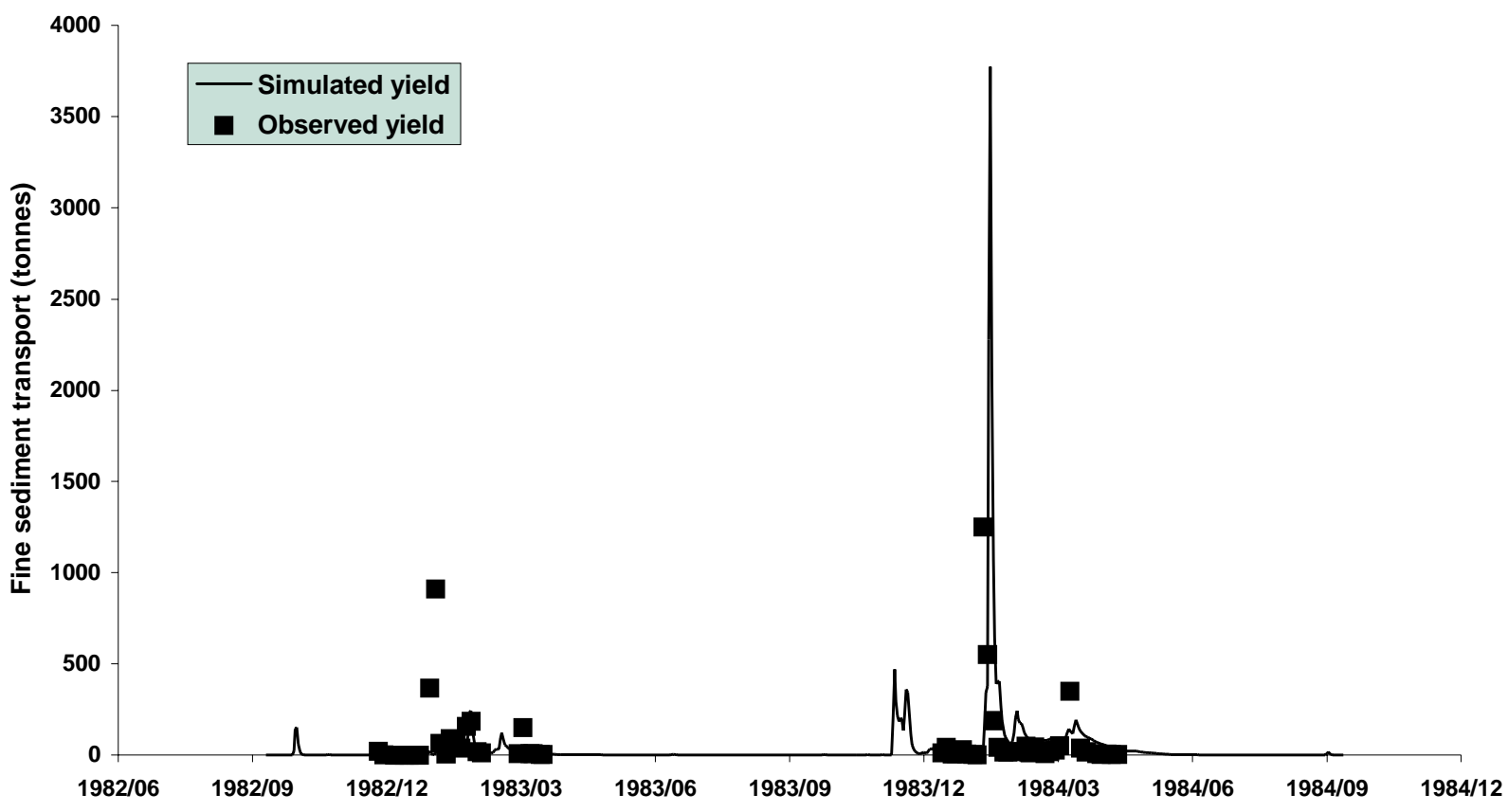

Figure 9

Time series plot of proxy basin validation of simulated sediment transport in the Nyatanda River

TABLE 4

Proxy basin validation of simulated transport at E 148 Nyatanda River $\left(682 \mathrm{~km}^{2}\right)$. The table gives average load during days with observations for the observation period 1 Oct 1982 to 30 Sept 1984.

\begin{tabular}{|l|c|c|}
\hline & $\begin{array}{c}\text { Average } \\
\text { sediment } \\
\text { transport (t/d) }\end{array}$ & $\begin{array}{c}\text { Difference } \\
\text { between } \\
\text { simulated and } \\
\text { observed } \\
\text { transport (\%) }\end{array}$ \\
\hline Observed & $\mathbf{8 7 . 8}$ & - \\
HBV-SED & 77.1 & -12 \\
HBV-SED original & 62.4 & -29 \\
Sediment rating curve & 54.3 & -38 \\
\hline
\end{tabular}

previous findings that the model fails to capture individual peaks correctly, but is capable of describing the sediment transport pattern and transported volumes fairly well. The proxy basin test also showed that for ungauged catchments, the accuracy increased when a more sophisticated model was applied( Table 4). The more advanced model, including distributed erosion information for the sub-basins (Eq. 4), gave better results, volume-wise, than the original HBV-SED model. These findings are in full agreement with the results of other studies of modelling performance in the region (e.g. Refsgaard and Knudsen, 1996). Under ungauged conditions an even better result would be expected if a fully distributed model, explicitly utilising information on catchment characteristics, had been adopted.

\section{Conclusions}

Detailed measurements of runoff and fine sediment concentration in the Odzi River showed large errors in the continuously monitored data for the 1998/99 wet season, illustrating the uncertainty in fine sediment prediction based on observed data in a sediment-prone 
river. Empirically-based models are especially sensitive to these errors since they are incorporated in the model by the calibration procedure.

Provided the observed data were fairly correct for the period studied, the HBV-SED model, calibrated for a 5-year period, predicted the volume of fine sediment transport reasonably well for the validation period, while it failed to simulate individual peaks accurately. The HBV-SED model gave explained variances similar to those obtained by the rating curve technique, which showed larger volume errors for fine sediment transport. Correctly simulated runoff on a daily basis was shown to be crucial for simulating the short-term dynamics of fine sediment transport.

The obtained HBV-SED parameters indicated that the fine sediment transport in the Odzi River was not significantly dependent on deposition within or close to the river channels, reducing the model's release routine to a sediment-rating curve function. However, the dynamics of the simulated HBV-SED storage variable gave time-varying intercept values for the release function, depending on the hydrological memory in the catchment studied, which resulted in a better volume estimation.

The inclusion of correction factors for spatially varying erosivity and seasonal vegetation cover in the HBV-SED model gave no visibly better model performance compared with the original model structure for the E61 site where observed data were available for calibration. However, the proxy-basin validation of the models at E148 showed that the more complex description of sediment accumulation improved the model results compared with the original HBV-SED model.

The results indicated that the length of the calibration period is of vital importance in the HBV-SED, illustrating the uncertainty in the prediction of fine sediment transport when observed records are short. At the E61 station in Odzi River a minimum of four years of fine sediment concentrations was needed for appropriate simulation of fine sediment transport volumes.

The suggested hydrological modelling approach to long-term sediment transport volume assessment may yield more accurate results than one based on conventional sediment rating curve methodology.

\section{Acknowledgements}

The authors gratefully acknowledge the help from the staff of the Hydrological Branch, Department of Water Development (DWD), Zimbabwe, especially Mr Elisha Madamombe and Mr Stuart Shumba who assisted during the field measurements. All rainfall data were obtained from the Department of Meteorology,Zimbabwe, and hydrological data were made available from DWD. The field measurement campaign was carried out within the framework of the GAMZ project (Gauging and Modelling of Runoff and Sediment in Zimbabwe) funded by the Swedish International Development Co-operation Agency (Sida).

\section{References}

ACKERS P and WHITE WR (1973) Sediment transport: New approach and analysis. J. Hydraul. Div. ASCE No HY 11.

ANDERSON IP, BRINN PJ, MOYO M and NYAMWANZA B (1993) Physical Resource Inventory of the Communal Lands of ZimbabweAn Overview. NRI Bulletin 60. Chatham, UK

BAGNOLD RA (1966) An approach to the sediment transport problem from general physics, US Geological Survey. Professional Paper 422I. Washington. $37 \mathrm{pp}$.

BEASLY DB, HUGGINS LF and MONKE EJ (1980) ANSWERS: A model for watershed planning. Trans. ASAE 23 938-944.
BERGSTRÖM S (1995). The HBV-model. In: SINGH VP (ed.) Computer Models for Watershed Hydrology. Water Resour. Public 443-476.

BRENT RP (1973) Algorithms for Minimisation without Derivatives. Englewood Cliffs, New Jersey Prentice-Hall.

CHABWELA HN (1991) Wetlands: A Conservation Programme for Southern Africa. IUCN/SADC, Maseru/Harare, Zimbabwe.

CHANSON H (1999) The Hydraulics of Open Channel Flow. Arnold.

CHENJE M and JOHNSON P (1996) Water in Southern Africa. SADC/ IUCN/SARDC, Maseru/Harare, Zimbabwe.

DUAN N (1983) Smearing estimate - A non-parametric retransformation method. J. Am. Stat. Ass. 78 605-610.

ELWELL HA (1981) A soil loss estimation technique for Southern Africa. In: Morgan RPC (ed.) Soil Conservation. Problems and Prospects. John Wiley and Sons.

ENGELUND F and HANSEN E (1967) A Monograph on Sediment Transport in Alluvial Streams. Teknisk Forlag, Copenhagen. 62 pp.

GREGORY KJ and WALLING DE (1973) Drainage Basin Form and Process - A Geomorphological Approach. Edward Arnold Ltd. London. $458 \mathrm{pp}$.

HARLIN J (1991) Development of a process oriented calibration scheme for the HBV hydrological model. Nordic Hydrol. 22 15-36.

HUDSON NW (1957) Erosion control research, progress report on experiments at Henderson Research Station 1953-56. Rhod. Agric. J. 54 (4) 297-323.

HUGHES DA (1997) Southern African "FRIEND" - The Application of Rainfall-Runoff Models in the SADC Region. WRC Report No. 235/ $1 / 97$.

JANSSON MB (1982) Land Erosion by Water in Different Climates. PhD Thesis, Uppsala Univ. UNGI Report No 57.

JANSSON MB (1996) Estimating a sediment rating curve of the Reventazón River at Palomo using logged mean loads within discharge classes. J. Hydrol. 183 227-241.

KARLSSON M and RAHMBERG M (1999) Assessment of Suspended Sediment Variability in the Odzi River, Zimbabwe. Minor Field Study No 53, Uppsala Univ., Sweden.

KLEMES V (1986) Operational testing of hydrological simulation models. Hydol. Sci. J. 311,3/1986 13-24.

LAHLOU A (1996) Environmental and socio-economic impacts of erosion and sedimentation in North Africa. In: Walling DE and Webb BW (eds.) Erosion and Sediment Yield: Global and Regional Perspectives. IAHS Publ. No 236.

LIDÉN R (1999) A new approach for estimating suspended sediment yield. Hydrol. Earth Syst. Sci. 3 (2) 285-294.

LINDSTRÖM G (1997) A simple automatic calibration routine for the HBV model. Nordic Hydrol. 28 153-168.

LINDSTRÖM G, GARDELIN M, JOHANSSON B, PERSSON M and BERGSTRÖM S (1997) Development and test of the distributed HBV96 hydrological model. J. Hydrol. 201 272-288.

LØRUP JK, REFSGAARD JC and MAZVIMAVID (1998) Assessing the effect of land use change on catchment runoff by combined use of statistical tests and hydrological modelling: Case studies from Zimbabwe. J. Hydrol. 205 147-163.

LØRUP JK and STYCZEN M (1996) Soil erosion modelling. In: Abbott MB and Refsgaard JC (eds.) Distributed Hydrological Modelling. Kluwer Academic Publisher. 93-120.

MAWERE G, HARLIN J and LIDÉN R (1999) Gauging and modelling for improved water development in Zimbabwe. In: Proc. of the $9^{\text {th }}$ Stockholm Water Symp. 372-374.

MORGAN RPC, QUINTON JN, SMITH RE, GOVERS G, POESEN JWA, AUERSWALD K, CHISCI G, TORRI D and STYCZEN ME (1998) The European Soil Erosion Model (EUROSEM): A dynamic approach for predicting sediment transport from fields and small catchments. Earth Surface Processes and Landforms 23 (6) 527-544.

NASH JE and SUTCLIFFE JV (1970) River flow forecasting through conceptual models. Part I - A discussion of principles. J. Hydrol. 10 282-290.

NORAD (1983) Soil and Water Conservation Vol 32, National Master Plan for Rural Water Supply and Sanitation Norwegian Agency for International Development.

REFSGAARD JC and KNUDSEN J (1996) Operational validation and intercomparison of different types of hydrological models. Water Res. Res. 32 (7) 2189-2202. 
ROOSEBOOM A (1992) The Development of the New Sediment Yield Map of Southern Africa. WRC Report No 279/1/92.

SCHULZERE(1995) Hydrology and Agrohydrology. A Text to Accompany the ACRU 3.00 Agrohydrological Modelling System. WRC Report No TT 69/95.

SMAKHTIN VY, WATKINS DA, HUGHES DA and SMAKHTINA OY (1998) Methods of catchment-wide assessment of daily low-flow regimes in South Africa. Water SA 24 (3) 173-185.

STOCKINGMA andELWELLHA (1973a) Soil erosion hazard in Rhodesia. Rhod. Agric. J. 70 (4) 93-101.

STOCKING MA and ELWELL HA (1973b) Prediction of subtropical storm losses from field plot studies. Agric. Meteorol. 12 193-201.

TARBOTON KC and SCHULZE RE (1991) The ACRU modelling system for large catchment water resources management. In: Van de Ven FHM, Gutknecht D, Loucks DP and Salewicz KA (eds.) IAHS Publ. $201219-232$.

USDA (1980) CREAMS - A Field-Scale Model for Chemical, Runoff and Erosion from Agricultural Management Systems, US Dept. of Agric. Conserv. Res. Report No 26. 640 pp.
VAN RIJN LC (1984) Sediment transport Part II: Suspended load transport. J. Hydraul. Eng. ASCE 110 (11) 1613-1641.

VAN RIJNLC (1993) Principles of Sediment Transport in Rivers, Estuaries and Coastal Seas. Aqua Publications- I11, Amsterdam.

WARD PRB (1980) Sediment transport and a reservoir siltation formula for Zimbabwe-Rhodesia. Die Siviele Ingenieur in Suid-Afrika.

WICKS JM and BATHURST JC (1996) SHESED: A physically based, distributed erosion and sediment yield component for the SHE hydrological modelling system. J. Hydrol. 175 213-238.

WILLIAMS JR (1975) Sediment yield prediction with universal equation using runoff energy factor. In: Present and Prospective Technology for Predicting Sediment Yield and Sources. USDA, ARS-40 244-252.

WMO (1980) Manual on Stream Gauging. Operational Hydrology Report No. 13, Geneva.

WURZEL P and WARD P (1982) Flood flow gauging with tritium in southern Africa. Adv. in Hydrom. IAHS Publ. 134 119-128. 